\title{
ARTICLE
}

\section{Health as Human Rights under National and International Legal Framework: Bangladesh Perspective}

\author{
Md. Ershadul Karim*
}

Few would dispute that good health is fundamental to a full and active life. It is the key to wealth and prosperity. Good health contributes directly to economic growth while poor health drives poverty. The right to health is considered directly in many international instruments including the World Health Organization. Every single country in the world is now a member of at least one of the many international instruments where health is treated as a human right. Sound health is a precondition to enjoy right to live peaceful. This right to health is guaranteed by the Constitution of the People's Republic of Bangladesh. If anybody in Bangladesh is deprived of enjoying his life then he can go to the court in order enforce his right. This paper aims at giving an overview of legal and regulatory framework of different international legal instruments and national laws of Bangladesh relating to healthcare and shares the response of Bangladesh Government in relation to the framework.

\section{Keywords}

Health, Human Rights, World Health Organization, Fundamental Rights, Fundamental Principles of State Policy, International Human Rights Instruments, Laws of Bangladesh

* Senior Research Officer, Chancery Research and Consultants Trust (CRC-Trust) [www.clcbd.org] and Advocate of the Bangladesh Supreme Court. LL.B. (Hons.)/LL.M. (Dhaka). The author may be contacted at: ershadulkarim@gmail.com/ Address: Suite \# 1101, Concord Tower, 11 th Floor, 113, Kazi Nazrul Islam Avenue, Dhaka, Bangladesh. 


\section{Introduction}

Few would dispute that health is wealth which is fundamental to a full and active life. 1 Good health contributes directly to economic prosperity, while poor health leads to poverty. According to Nobel Laureate Amartya Sen, men can enjoy the maximum freedom when they are free from health problem. ${ }^{2}$ Securing health is therefore important to human well-being. Against this backdrop, the right to health is considered directly in many international instruments. As the World Health Organization ("WHO") has revealed that every country in the world is now a member of at least one of these international instruments, 3 few people dispute that sound health is a pre-condition to enjoy the right to life.

As the traditional police state redefines its role in the welfare state system, 4 State not only performs sovereign functions, but also seeks to ensure social security and welfare for people. Health is what most countries put the highest priority on. This paper aims to examine how various international legal instruments view the physical and mental health issue from the perspective of human right. In addition, it explores how it is applied to the national law of Bangladesh. The human right to health has been always embodied within the "right to life." Unfortunately, the "right to health" has not received considerable attentions in many parts of the world, including Bangladesh. This paper intends to initiate the discussion about such an important and timely issue and to provide guidelines for the countries on how to determine their international obligations to support it.

This paper is composed of four parts. The first part will discuss conceptual issues in health and human rights, etc. The second part will analyze the provisions relating to health in different international legal instruments. The third part will address questions on the implementation of international human rights instruments. The final part will discuss how Bangladesh government handles the issue of health as human rights at the national level.

\footnotetext{
For details, see L. Doyal \& I. Gough, A Theory of Human Need (1991).

S. Amartya, Health in Development, 77 Bull. THE World HeALth ORG. 619 (1999).

WHO, HEALth AND Hum. RIGHT, available at http://www.who.int/hhr/en/ (last visited on Nov. 11, 2008).

The phrase 'Welfare State' was probably first used by Archbishop William Temple in 1941 in his pamphlet "Citizen and Churchman." See P. GregG, The Welfare State 3-4 (1967).
} 


\section{Right to Health as Human Right}

\section{A. What is Health?}

It is not easy to find the universal definition of the term 'health' since the word carries several different meanings. In the Oxford dictionary, "health' is defined as "he state of being well and a state free from illness in body or mind." 5 It also implies the condition of a person's body or mind.6 It is the extent of continuing physical, emotional, mental, and social ability to cope with one's environment. ${ }^{7}$

The WHO Constitution of 1946 defines health as "a state of complete physical, mental and social well-being and not merely the absence of disease or infirmity." 8 This definition is also referred and supplemented by the Ottawa Charter for Health Promotion of 1986, which defines 'health' as "a resource for everyday life, not the objective of living. Health is a positive concept emphasizing social and personal resources, as well as physical capacities." 9 In the WHO's definition, health is defined in terms of ultimate goal of perfection. The WHO has also specified particular objectives to be reached on the way to this ideal.10 Article I of the Alma-Ata Declaration of 1978 defines health as "a state of complete physical, mental and social well being, and not merely the absence of disease or infirmity." 11

In Bangladesh, there is no law which directly defines 'health.' Even the Public Health (Emergency Provisions) Ordinance of 1944 (Ordinance No. XXI of 1944) fails to define the term, either. Nevertheless, section 2 (e) of the Ordinance provides that "public health services" and "public health establishment" include sanitary, watersupply, vaccination, sewerage disposal, drainage and conservancy services and establishment maintained for the purposes of such services, and any other service or establishment of a local authority. This perspective on public health suggests that there

\footnotetext{
See OXFoRd AdVANCED LEARNER's DictionARY WITH WORKSHEETS 551 (5th ed. 1999). Id.

See 4 BRItannica Ready ReFERENCE EncyClopedia (India) 276 (2005).

The Constitution of the World Health Organisation ("WHO Constitution"), Pmbl. (2nd Para.)

9 The Ottawa Charter for Health Promotion (adopted at the First International Conference on Health Promotion on Nov. 12, 1986) See WHO/HPR/HEP/95.1, available at http://www.who.int/hpr/NPH/docs/ottawa_charter_hp.pdf (last visited on Nov. 11, 2008).

10 WHO, Targets for Health for All: Targets in Support of the Regional Strategy for Health for All by the Year 2000 (1985). For a commentary on this document, see D. Sharp, Health for All by the Year 2000: Information Targets. National Goals?-No National Targets?, 4 HeALth Libraries Rev. 219-224 (1987), available at http://onlinelibrary.wiley.com/doi/10.1046/j.1365-2532.1987.440219.x/pdf (last visited on July 31, 2010).

11 The Alma-Ata Declaration (1978), art. 1, available at http://www.who.int/hpr/NPH/docs/declaration_almaata.pdf (last visited on July 31, 2010).
} 
is an interrelation between sanitary, water-supply, vaccination, sewerage disposal, drainage and conservancy services. In this context, health can be defined in the following three ways: Negatively, it is the absence of illness; positively, it is fitness and well-being; and functionally, it is the ability to cope with everyday activities. Health is a resource for everyday life. It is a basic and dynamic force in our daily lives, influenced by our circumstances, beliefs, culture and social, economic and physical environments.

\section{B. Defining Human Rights in Relation to Health}

Human rights are universally inherent, inalienable and inviolable rights of all mankind. States and their public authorities must ensure human rights for the people. 12 Human rights are concerned with the dignity and worth of the individuals and "represent minimal moral standards for human society." 13

On the basis of the three watchwords of the French Revolution such as Liberty, Equality and Fraternity, the Czech jurist, Carel Vasak divided human rights into three generations. The first-generation concerns with civil and political rights. They were the brain child of Western democratic countries. The first-generation includes right to life, liberty, security to persons, freedom of assemble, freedom of association, and freedom of religion. The second-generation focuses on economic, social and cultural rights. They were traditionally supported by socialist countries. The second-generation of human rights discourse includes right to employment, right to housing, and right to equal wage. The third generation human rights emerge with the United Nations with the Stockholm Declaration on the Human Environment. The third-generation of human rights includes group and collective rights, such as right to self-determination right to environment and right to development.

\section{Health and Human Rights}

Health is a crucial condition to enjoy other human rights though usually encapsulated within the right to life. All human rights contain such actions as right to life, security to person, right to water, right to information, right to education, right to rood and nutrition, freedom of movement, right to participation, harmful traditional practices, freedom from violence, torture, slavery, freedom from discrimination and the right to privacy. These are closely interlinked with health. It is depicted as Diagram II-1.

\footnotetext{
Ershadul Bari, Human Rights and World Peace 1 (DhaKa Univ. Stud., Pt.F, vol. III, 1992).

13 Morris B. Abram, Freedom of Thought, Conscience and Religion, 8 J. InT'L Comm'n of JURISTs 40 (1967), quoted by Bari, supra note 12.
} 
Diagram II-1: Examples of the Linkage between Health and Human Rights

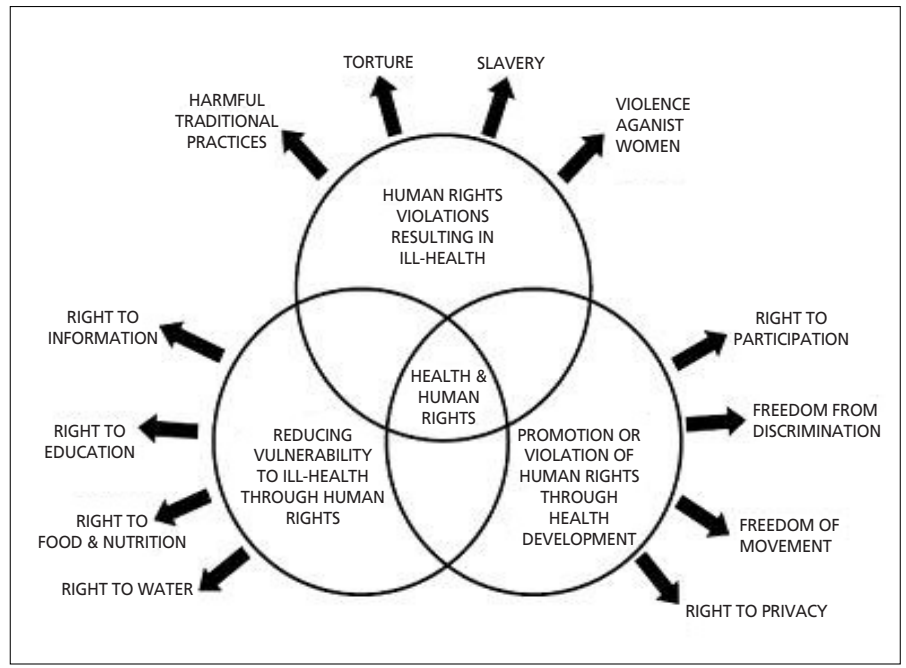

Source: WHO, Linkage between Health and Human Rights.

(http://www.who.int/hhr/HHR\%20linkages.pdf)

\section{Health-Related Issues in International Legal Instruments}

\section{A. Concern for Health under International Law}

The concern for 'health' is a new issue of the postwar period. At the time of creating the United Nations, the drafting committee, realized the importance of this issue, and included provisions relating to health in the Charter. The Charter of the United Nations empowers (a) the General Assembly to initiate studies and make recommendations for the purpose of ... promoting international co-operation in the . .health fields, 14 and (b) the Economic and Social Council may make or initiate studies and reports with respect to international ... health, and related matters and may make recommendations with respect to any such matters to the General Assembly to the Members of the United Nations, and to the specialized agencies concerned.15 The United Nations is responsible for "promoting solutions of international ... health, and 
related problems with a view to the creation of conditions of stability and well-being which are necessary for peaceful and friendly relations among nations based on respect for the principle of equal rights and self-determination of peoples." 16 If considering 'health' within the context of "right to life," hundreds of references may be found in international human rights instruments such like conventions, treaties, 17 declarations, norms and standards. 18 Many legal instruments on health were regionally adopted in Africa, America, Arab and Europe as well.19

\section{B. International Legal Instruments for Health}

\section{Article 25 of the Universal Declaration of Human Rights of 1948 ("UDHR") provides}

16 Id. art. 55, para. b.

17 The Convention on the Prevention and Punishment of the Crime of Genocide, 1948, the Convention for the Suppression of the Traffic in Persons and of the Exploitation of the Prostitution of Others (1949), the First Geneva Convention for the Amelioration of the Condition of the Wounded and Sick in Armed Forces in the Field (1949), the Second Geneva Convention for the Amelioration of the Condition of Wounded, Sick and Shipwrecked Members of Armed Forces at Sea (1949), the Third Geneva Convention Relative to the Treatment of Prisoners of War (1949), the Fourth Geneva Convention Relative to the Protection of Civilian Persons in Time of War (1949), the Convention Relating to the Status of Refugees (1950) and the Protocol Relating to the Status of Refugees (1967), the International Convention on the Elimination of All Forms of Racial Discrimination (1963), the International Covenant on Economic, Social and Cultural Rights (1966), the International Covenant on Civil and Political Rights (1966) \& its Protocol of 1966, the First Additional Protocol to the Geneva Conventions Relating to the Protection of Victims of International Armed Conflicts (1977), the Second Additional Protocol to the Geneva Conventions Relating to the Protection of Victims of Non-International Armed Conflicts (1977), the Convention on the Elimination of All Forms of Discrimination Against Women (1979) and its Optional Protocol of 1999, the Convention Against Torture and Other Cruel, Inhuman or Degrading Treatment or Punishment (1984), the Second Optional Protocol on the Abolition of the Death Penalty (1989), the Convention on the Rights of the Child (1989), the International Convention on the Protection of the Rights of All Migrant Workers and Members of their Families (1990), the Convention on the Rights of Persons with Disabilities (2007).

18 The Declaration on the Use of Scientific and Technological Progress in the Interests of Peace and for the Benefit of Mankind (1975), the Principles of Medical Ethics relevant to the Role of Health Personnel, particularly Physicians, in the Protection of Prisoners and Detainees against Torture and Other Cruel, Inhuman or Degrading Treatment (1982), the Declaration on the Right to Development (1986), the Principles for the Protection of Persons with Mental Illness and the Improvement of Mental Health Care (1991), the Declaration on the Rights of Persons Belonging to National or Ethnic, Religious and Linguistic Minorities (1992), the Declaration on the Right and Responsibility of Individuals, Groups and Organs of Society to Promote and Protect Universally Recognized Human Rights and Fundamental Freedoms (1998).

19 The African Charter on Human and Peoples Rights (1981), the African Charter on the Rights and Welfare of the Child (1990), the American Declaration of the Rights and Duties of Man (1948), American Convention on Human Rights (1969) and its Protocol of 1990, the Inter-American Convention to Prevent and Punish Torture (1985), the Additional Protocol to the American Convention on Human Rights in the Area of Economic, Social and Cultural Rights - Protocol of San Salvador (1988), the American Convention on the Prevention, Punishment and Eradication of Violence against Women Convention of Belem do Para (1994), the Inter-American Convention on the Elimination of All Forms of Discrimination Against Persons With Disabilities (1999), the Arab Charter on Human Rights (1994), the European Convention for the Protection of Human Rights and Fundamental Freedoms (1950), European Social Charter (1961, revised 1996), the European Convention on Human Rights and Dignity of the Human Being with regard to the Application of Biology and Medicine: Convention on Human Rights and Biomedicine (1997). 
that "everyone has the right to a standard of living adequate for the health and wellbeing of himself and his family including food, clothing, and medical care." Second, Article 12 of the International Covenant on Economic, Social and Cultural Rights of 1966 ("ICESCR") provides that "the States being Parties to the present Covenant recognize the right of everyone to the enjoyment of the highest attainable standard of physical and mental health." This article also provides that "in doing so the state parties shall take necessary steps to ensure reduction of the stillbirth-rate of infant mortality and for the healthy development of the child; to improve all aspects of environmental and industrial hygiene; to prevent, treat and control epidemic, endemic, occupational and other diseases; and create conditions which would assure to all medical service and medical attention in the event of sickness.” The Universal Declaration on the Human Genome and Human Rights of 1997 contains similar provisions relating to health. 20 Third, point 11 of Part I of the European Social Charter of 1961 provides that "everyone has the right to benefit from any measures enabling him to enjoy the highest possible standard of health attainable." Point 12 of Part II of the European Social Charter of 1961 dealing with the right to protection of health also provides that " $[\mathrm{w}] \mathrm{ith}$ a view to ensuring the effective exercise of the right to protection of health, the Contracting Parties undertake, either directly or in co-operation with public or private organizations, to take appropriate measures designed inter alia: (1) to remove as far as possible the causes of ill-health; (2) to provide advisory and educational facilities for the promotion of health and the encouragement of individual responsibility in matters of health; and (3) to prevent as far as possible epidemic, endemic and other diseases. Fourth, Article XI of the American Declaration of the Rights and Duties of Man of 194821 provides that "every person has the right to the preservation of his health through sanitary and social measures relating to food, clothing, housing and medical care, to the extent permitted by public and community resources." Fifth, Article 16 of the African [Banjul] Charter on Human and Peoples' Rights of 1981 provides that "every individual shall have the right to enjoy the best attainable state of physical and mental health.” The African Charter on Human and Peoples' Rights also made it obligatory for State Parties to take necessary measures to protect the health of their people and to ensure that they receive medical attention when they are sick. Sixth, Article 13 of the Arab Charter on Human Rights of 1994 and Article 3 of the Commonwealth of Independent States Convention on Human Rights

20 See UNESCO Gen. Conf. Res. 29 C/Res.16, reprinted in Records of the General Conference, UNESCO, 29th Sess., 29 C/Res. 19, at 41 (1997) (adopted by the UN General Assembly, G.A. Res. 152, U.N. GAOR, 53rd Sess., U.N. Doc. A/RES/53/152 (1999)).

21 O.A.S. Res. XXX (adopted by the 9th International Conference of American States of 1948), reprinted in Basic Documents Pertaining to Human Rights in the Inter-American System, OEA/Ser.L.V/II.82 Doc.6 rev.1, at 17 (1992). 
of 2000 prohibit medical or scientific experimentation on any person without his free consent.

According to those in instruments and resolutions, the health-related issue is demanding more attention from the international community. Noticeable is that the Universal Declaration on Human Rights links health to the standard of living, though all other instruments treat health as an independent right to life in general. Though most international human rights instruments only deal with physical health, the ICCPR includes both 'physical' and 'mental' health. 22 Both the ICCPR and the European Social Charter define the right in terms of the 'highest' standard of health 'attainable.'

Together, the International Labor Organization ("ILO") adopted many conventions relating to occupational safety and health. They are as follows: the Convention on Medical Examination of Young Persons (Industry) of 1946 (Convention No. 77), the Convention on Medical Examination of Young Persons (Non-Industrial Occupations) of 1946(Convention No. 78), the Convention on Employment Injury Benefits of 1964 (Convention No. 121), the Convention on Medical Examination of Young Persons (Underground Work) of 1965 (Convention No. 124), the Convention on Occupational Health Services of 1985 (Convention No. 161), the Convention on the Prohibition and Immediate Action for the Elimination of the Worst Forms of Child Labor of 1999 (Convention No. 182), the Convention on the Maternity Protection of 2000 (Convention No. 183). 23

\section{State Obligations under the International Legal Instruments}

\section{A. Common Obligations for Health}

All international legal instruments have sought to achieve their objectives stated in their preambles. They impose some obligations on the State parties in order to fulfill their intentions. All parties who signed and ratified these instruments are bound to the obligations therein.

Some common obligations under these international instruments include: (a) adoption of all appropriate legislative, administrative and other measures for the

22 ICCPR, art. 12.

23 ILO, Database of International Labour Standards, available at http://www.ilo.org/ilolex/english/convdisp1.htm (last visited on July 31,2010 ). 
implementation of the rights recognized in the instrument;24 (b) taking of appropriate measures, including legislation, to modify or abolish existing laws, regulations, customs and practices that are against the spirit of the matter of the instrument; 25 (c) refrain from engaging in any act or practice is inconsistent with the instrument; 26 (d) ensuring public authorities and institutions to act in conformity with the provision of the instrument; (e) undertaking or promoting research and development on issues relating to the instrument; 27 (f) provision of accessible information relating to the provision of the instrument; and $(\mathrm{g})$ submission of periodical reports on issues relating to the instrument. 28

In terms of enforcement, some human rights are derogable. A State may sometimes suspend the enforceability of these rights on the ground of public emergency which "threatens the life of the nation." There are some rights on the enforcement of which limitation can be imposed on some grounds, such as "prescribed by law, in a democratic society, public order, public health, public morals, national security, public safety, rights and freedoms of others, or rights and reputations of others, restrictions on public trial." 29

\section{B. Two Covenants}

On the other hand, there are some rights which are not derogable. No state party shall, even in time of emergency threatening the national security, derogate the following rights guaranteed by the ICCPR: the right to life, freedom from torture, cruel, inhuman or degrading treatment or punishment, and from medical or scientific experimentation without free consent; freedom from slavery or involuntary servitude; the right not to be imprisoned for contractual debt; the right not to be convicted or sentenced to a heavier penalty by virtue of retroactive criminal legislation; the right to recognition as a person before the law; 30 and freedom of thought, conscience and religion. These rights are not derogable under any conditions or circumstances even for the national security. ${ }^{31}$ In accordance with the African Charter on Human and Peoples' Rights, the

E.g., see Articles 2(1)(c) \& 4 of the Convention on the Elimination of All Forms of Racial Discrimination of 1965, the Child Rights Convention of 1989, Limburg Principles on the Implementation of the International Covenant on the Economic, Social and Cultural Rights, available at http://www.unhchr.ch/tbs/doc.nsf/0/6b748989d76d2bb8c 125699700500e17?Opendocument (last visited on July 31, 2010).

25 The Convention on the Elimination of Discrimination against Women (1979), art. 2(f).

26 Id. art. 2(d).

27 The Convention on the Rights of Persons with Disabilities (2006), art. 4(f) \& (g).

28 The International Convention on the Elimination of All Forms of Racial Discrimination (1965), art. 9.

29 ICCPR, art 12(3). See also The American Convention on Human Rights, art.13.

30 ICCPR, art. 4.

31 See the Siracusa Principles on the Limitation and Derogation Provisions in the ICCPR. See U.N. Doc. E/CN.4/1985/4, Annex (1985). 
States have immediate obligation to ensure health for all.32 The ICESCR also requires the State parties to take necessary measures in support of the right to health and to prevent endemic and other diseases. 33 This obligation is also stipulate under the European Social Charter. 34

\section{United Kingdom Patient's Charter}

Inspired and influenced by such instruments, many States in the international community have changed their legal systems. For example, the United Kingdom enacted the Human Rights Act in 1998,35 which mostly incorporated the European Convention on Human Rights and Fundamental Freedoms of 1950. The U.K. Human Rights Act, however, does not include a positive right to health care equivalent to Article 25 of the Universal Declaration of Human Rights. Instead, the United Kingdom proclaimed the Patient's Charter in 1991.36 It aims at improving the quality of health service delivery to patients and sets out patients' rights in the National Health Service in areas such as waiting times, information about services and treatment, and privacy and dignity of the patient. The United Kingdom established the Health Service Commissioner in 1973 following the National Health Service Reorganization Act. The Commissioner is empowered to set out under the Health Service Commissioners Act of 1993.37 There were supposed to be three National Health Service Ombudsmen. Among them, the general Ombudsman mainly performs the duties with the help of a Deputy Commissioner.

In addition, the European Court of Human Rights and the European Commission of Human Rights dealt with a good number of cases on health issue, especially concerning the relationship among medical treatment, the right to life and degrading treatment. For example, in the unreported case of Tanko v. Finland Appl., the Commission, explicitly refusing the possibility to exclude the relationship, held that: ". . . a lack of proper medical care in a case where someone is suffering from a serious illness could in certain circumstances amount to treatment contrary to Article 3." 38 In the case of Association X v. UK, the Commission decided a case concerning a

\footnotetext{
The African Charter on Human and Peoples' Rights (1981), art. 16(2).

3 ICESCR, art. 12(2)(c).

4 The European Social Charter, Pt. II, para. 11.

35 The Human Rights Act of 1998 (Ch. 42), available at http://www.legislation.gov.uk/ukpga/1998/42 (last visited on July 31,2010$)$.

36 UK Department of Health, The Patient's Charter (1991), available at http://www.pfc.org.uk/node/ 633\#charter (last visited on July 31, 2010).

37 The National Health Service Reorganization Act was amended by the Health Service Commissioners Act of 1996, the National Health (Primary Care) Act of 1997, the Health Act of 1999 and the Health Services Commissioners Act of 2000.

38 Appl. No. 23634/94 (1994); 77 EuR. Comm'N H.R. DEC. \& REP. 133 and Appl. No. 30913/96 (1994).
} 
complaint about a voluntary vaccination scheme. ${ }^{39}$ In the case of $X$ v. Ireland, it is decided whether the state is responsible for providing free medical care for those whose lives are at risk. 40 Likewise, in the case of Hughes v. UK, it is decided whether the health professionals are in charge of taking prompt medical action in emergencies. 41 In the case of D v. United Kingdom, a patient of St. Kitts who was staying in the UK with a terminal and incurable illness was compelled to leave UK on the ground of health security of other citizens. 42 The decision of the UK Authority, however, was challenged and claimed in that if patient was compelled to leave he would not get sufficient medical, social and other forms of assistance. The European Court of Human Rights held that:

In view of these exceptional circumstances and bearing in mind the critical stage now reached in the applicant's fatal illness, the implementation of the decision to remove him to St. Kitts would amount to inhuman treatment by the respondent State in violation of Article 3 of the Convention (European Convention on Human Rights, 1950). 43

\section{Implementation of Health Related Issues in International Level}

Joining international legal instruments is insufficient in itself without implementation. When State becomes a party to an international legal instrument such as convention, covenant, agreement, multilateral or bilateral treaty, that State shall follow the provisions of the instrument under the principle of pacta sunt servenda. When the state shall ratify the instrument, the provisions shall be applicable against the state. Almost all international legal instruments provide for implementation mechanisms such as (a) establishment of committees or watchdog bodies, 44 (b) periodic reports, (c) inter-state communication, etc. The committees are responsible for monitoring overall implementation of the instrument

3914 Eur. Comm'n H.R. DEC. \& ReP. 31, 32, App No. 7154/75 (1978) .

407 EUR. COMM'N H.R. DEC. \& REP. 78.

4148 Eur. Comm'n H.R. DEC. \& ReP. 258, App No. 11590/85 (1986).

4224 EUR. HUM. RTS. REP. 423 (1997).

43 D v. United Kingdom (1997) 24 EuR. Hum. RTs. ReP. 423, Para. 53. See also European Commission's decision in B v. France [1998] EuR. Hum. RTs. L. REV. 620.

44 Article 33(1) of the Convention on the Rights of Persons with Disabilities provides that each state party shall designate one or more focal points within government for matters relating to the implementation of the Convention, and shall give due consideration to the establishment or designation of a coordination mechanism within government to facilitate related action in different sectors and at different levels. 
and for initiating necessary actions. The instruments also provide that the state parties should inform the international community about issues relating to the instruments through periodic reports. Also, some international legal instruments deal with inter-state complaints, and individual communication, etc., in case there is a violation of the provisions. 45 Regarding individual communications, for example, the Human Rights Committee may consider individual communications under the First Optional Protocol to the International Covenant on Civil and Political Rights; CEDAW may consider individual communications relating to States parties to the Optional Protocol to the Convention on the Elimination of Discrimination Against Women.

The WHO is mainly in charge of monitoring health issue of global significance. The objective of the $\mathrm{WHO}$ is to ensure that all peoples maintain the highest possible level of health conditions. 46 The WHO Constitution stipulates those principles in its Preamble.47 Table V-1 provides the details.

\section{Table V-1: The WHO Constitutional Principles}

\begin{tabular}{|c|l|}
\hline A & $\begin{array}{l}\text { The enjoyment of the highest attainable standard of health is one of the } \\
\text { fundamental rights of every human being without distinction of race, religion, } \\
\text { political belief, economic or social condition. }\end{array}$ \\
\hline B & $\begin{array}{l}\text { The health of all peoples is fundamental to the attainment of peace and security } \\
\text { and is dependent upon the fullest co-operation of individuals and States. }\end{array}$ \\
\hline C & $\begin{array}{l}\text { The achievement of any State in the promotion and protection of health is of value } \\
\text { to all. }\end{array}$ \\
\hline D & $\begin{array}{l}\text { Unequal development in different countries in the promotion of health and } \\
\text { control of disease, especially communicable disease, is a common danger. }\end{array}$ \\
\hline E & $\begin{array}{l}\text { Healthy development of the child is of basic importance; the ability to live } \\
\text { harmoniously in a changing total environment is essential to such development. }\end{array}$ \\
\hline $\mathrm{F}$ & $\begin{array}{l}\text { The extension to all peoples of the benefits of medical, psychological and related } \\
\text { knowledge is essential to the fullest attainment of health. }\end{array}$ \\
\hline $\mathrm{G}$ & $\begin{array}{l}\text { Informed opinion and active co-operation on the part of the public are of the } \\
\text { utmost importance in the improvement of the health of the people. }\end{array}$ \\
\hline $\mathrm{H}$ & $\begin{array}{l}\text { Governments have a responsibility for the health of their peoples which can be } \\
\text { fulfilled only by the provision of adequate health and social measures. }\end{array}$ \\
\hline
\end{tabular}

Source: The WHO Constitution, Pmbl.

45 See Convention against Torture and Other Cruel, Inhuman or Degrading Treatment or Punishment of 1984, art. 21; International Convention on the Protection of the Rights of All Migrant Workers and Members of Their Families of 1990, art. 74 .

46 The WHO CONST. art 1.

47 Id. Pmbl. 
The WHO is a specialized agency of the United Nations. Each year, the WHO sets a theme or slogan on its foundation day (April 7) 48 and emphasizes on the issue of slogan or theme of that particular year along with other general or on-going activities. Thus, the WHO is primarily responsible for monitoring health issues all over the world and performs the charter-based duty of the United Nations. It shall be supervised by the Economic and Social Council ("ECOSOC") under the ICCPR.

Together with the WHO which is the general authority for the improvement of health condition all over the world, there are different health-related organizations like the World Medical Association ("WMA"),49 the World Psychiatric Association

48 The following are the themes of the WHO after its foundation (the figures in bracket indicate the year).

Know Your Own Health Services (1950), Health for Your Child and the World's Children (1951), Health Surrounding Make Healthy People (1952), Health is Wealth (1953), The Nurse, Pioneer of Health (1954), Destroy Disease Carrying Insects (1955), Food for Health (1956), Ten Years of Health Progress (1958), Mental Illness and Mental Health in the World Today (1959), Malaria Eradication - A World Dealing (1960), Accidents Need Not Happen (1961), Preserve Sight Prevent Blindness (1960), Hunger Disease of Millions(1961), No Truce for Tuberculosis (1964), Smallpox - Constant Alert (1965), Man and His Cities (1966), Partners in Health (1967), Health in the World of Tomorrow (1968), Health, Labor and Productivity (1969), Barely Detection of Cancer Saves Lives (1970), A Full Life Despite Diabetes (1971), Your Heart is Your Health (1972), Health Begins at Home (1973), Better Food for a Healthier World (1974), Smallpox - Points of No Return (1975), Foresight Prevents Blindness (1976), Immunize and Protect Your Child (1977), Down with High Blood Pressure (1978), A Healthy Child - A Sure Future (1979), Smoking or Health : the Choice is Yours (1980), Health for All by the Year 2000 (1981), Add Your Life to Years (1982), Health for All by the Year 2000: the Count Down Has Begun (1983), Children's Health Tomorrow's Wealth (1984), Healthy Youth: Our Best Resource (1985), Healthy Living : Every One a Winner (1986), Immunization : a Change for Every Child (1987), Health For All - All For Health (1988), Lets Talks Health (1989), Our Planet Our Health. Think Globally - Act Locally (1990), Should Disaster Strike - Be Prepared (1991), Heartbeat the Rhythm of Health (1992), Handle Life with Care; Prevent Violence and Negligence (1993), Oral Health for a Healthy Life (1994), A World without Polio - Target 2000 (1995), Healthy Cities for Better Life (1996), Emerging Infection Diseases: Global Alert Response (1997), Pregnancy is Special: Let's Make it Safe (1998), Active Aging Make the Difference (1999), Safe Blood Starts With Me, Blood Save Lives (2000), Stop Exclusion - Dare to Care (2001), Move for Health (2002), Shape the Future of Life : Health Environments for Children (2003), Road Safety (2004), Working Together for Health (2006), Invest in Health, Build a Safer Future (2007), Protecting Health from Climate Change (2008), Save Lives. Make Hospitals Safe in Emergencies (2009), 1000 Cities, 1000 Lives (2010).

49 The World Medical Association is a federal organization of National Medical Associations. The WMA adopted many instruments, some of which are as follows: the Declaration Concerning Support for Medical Doctors Refusing to Participate in, or to Condone, the Use of Torture or Other Forms of Cruel, Inhuman or Degrading Treatment, 1997 (Adopted by the 49th WMA General Assembly, Hamburg, Nov. 1997); the Declaration on Human Rights and Individual Freedom of Medical Practitioners, 1985 (Adopted by the 37th World Medical Assembly, Brussels, Belgium, October 1985); the Declaration on Hunger Strikers (Declaration of Malta), 1991 and 1992 (Adopted by the 43rd World Medical Assembly, Malta, November 1991, and editorially revised at the 44th World Medical Assembly, Marbella, Spain, September 1992); the Guidelines for Medical Doctors Concerning Torture and Other Cruel, Inhuman or Degrading Treatment or Punishment in Relation to Detention and Imprisonment (Declaration of Tokyo), 1975 (Adopted by the 29th World Medical Assembly, Tokyo, Japan, October 1975); the International Code of Medical Ethics, 1948, 1994 (Adopted by the 2nd General Assembly of the World Medical Association, Geneva, Switzerland, September 1948, and amended by the 22nd World Medical Assembly, Sydney, Australia, August 1968, and the 35th World Medical Assembly, Venice, Italy, October 1983, and the 46th WMA General Assembly, Stockholm, Sweden, September 1994); the Statement on the Licensing of Physicians Fleeing Prosecution for Serious Criminal Offences, 


\section{("WPA"),50 the International Council of Nurses ("ICN"), 51 the United Nations, 52 the}

1997 (Adopted by the 49th WMA General Assembly, Hamburg, Germany, November 1997); the Regulations in Time of Armed Conflict, 1956 (Adopted by the 10th World Medical Assembly, Havana, Cuba, October 1956, edited by the 11th World Medical Assembly, Istanbul, Turkey, October 1957, and amended by the 35th World Medical Assembly, Venice, Italy, October 1983); the Resolution on Physician Participation in Capital Punishment, 1981 (Adopted by the 34th World Medical Assembly, Lisbon, Portugal, September 28 - October 2, 1981); the Statement on Body Searches of Prisoners, 1993 (Adopted by the 45th World Medical Assembly, Budapest, Hungary, October 1993), the Statement on Condemnation of Female Genital Mutilation, 1993 (Adopted by the 45th World Medical Assembly, Budapest, Hungary, October 1993).

50 The WPA is an association of national psychiatric societies aimed to increase knowledge and skills necessary for work in the field of mental health and the care for the mentally ill. Its member societies are presently 135, spanning 117 different countries and representing more than 200,000 psychiatrists. The WPA organizes the World Congress of Psychiatry every three years. It also organizes international and regional congresses and meetings, and thematic conferences. It has 65 scientific sections, aimed to disseminate information and promote collaborative work in specific domains of psychiatry. It has produced several educational programs and series of books. It has developed ethical guidelines for psychiatric practice, including the Madrid Declaration (1996). See WPA, About the World Psychiatric Association, available at http://www.wpanet.org/detail.php?section_id=5\&content_id=4 (last visited on July 31, 2010).

51 The ICN is a federation of more than 130 national nurses associations (NNAs), representing the more than 13 million nurses worldwide. Founded in 1899, ICN is the world's first and widest reaching international organization for health professionals. See ICN, About the ICN, available at http://www.icn.ch/about-icn/about-icn (last visited on July 31, 2010). The following are legal instruments adopted by the ICN: the ICN Statement on Elimination of Female Genital Mutilation, (adopted in 1995, Revised in 2004); the ICN Statement on Nurses and Human Rights, 1983 (Replaces previous ICN Position: “The Nurse's Role in Safeguarding Human Rights," adopted 1983, updated 1993); the Nurse's Role in the Care of Prisoners and Detainees, 1998 (Replaces previous ICN Position: The Nurse's Role in the Care of Detainees and Prisoners, adopted 1975); the ICN Statement on Torture, Death Penalty and Participation by Nurses in Executions (Replaces previous ICN Positions "Nurses and Torture," adopted 1989 and "Death penalty and participation by nurses in execution" adopted 1989).

52 The following are health-related instruments adopted by the United Nations. the Principles of Medical Ethics relevant to the Role of Health Personnel, particularly Physicians, in the Protection of Prisoners and Detainees against Torture and Other Cruel, Inhuman or Degrading Treatment or Punishment, 1982 (Adopted by UN General Assembly resolution 37/194 of December 18, 1982); Basic Principles for the Treatment of Prisoners (Adopted and proclaimed by General Assembly resolution 45/111 of December 14, 1990); Body of Principles for the Protection of All Persons under Any Form of Detention or Imprisonment (Adopted by General Assembly resolution 43/173 of December 9, 1988), the Convention on the Prevention and Punishment of the Crime of Genocide, Approved and proposed for signature and ratification or accession by General Assembly resolution 260 A (III) of December 9, 1948, entry into force January 12, 1951, in accordance with article XIII; the Convention against Torture and Other Cruel, Inhuman or Degrading Treatment or Punishment, adopted and opened for signature, ratification and accession by General Assembly resolution 39/46 of December 10, 1984, entry into force June 26, 1987, in accordance with article 27 (1); the Convention on the Rights of the Child, 1989, adopted and opened for signature, ratification and accession by General Assembly resolution 44/25 of November 20, 1989, entry into force September 2, 1990, in accordance with article 49; the International Covenant on Civil and Political Rights, 1966, adopted and opened for signature, ratification and accession by General Assembly resolution 2200A (XXI) of December 16, 1966, entry into force March 23, 1976, in accordance with Article 49; the International Covenant on Economic, Social and Cultural Rights, 1966, adopted and opened for signature, ratification and accession by General Assembly resolution 2200A (XXI) of December 16, 1966, entry into force January 3, 1976, in accordance with article 27; the Declaration on the Protection of All Persons from Being Subjected to Torture and Other Cruel, Inhuman or Degrading Treatment or Punishment, 1975, adopted by General Assembly resolution 3452 (XXX) of December 9, 1975; the Declaration on the Rights of Disabled Persons, 1975, proclaimed by General Assembly resolution 3447 (XXX) of December 9, 1975; the Declaration on the Rights of Mentally Retarded Persons, proclaimed by General Assembly resolution 2856 (XXVI) of 
Amnesty International, 53 the International Council of Prison Medical Services ("ICPMS"), 54 the International Union of Psychological Science ("IUPSyS"),55 and International Federation of Gynecology and Obstetrics ("FIGO").56 They have been contributing considerably on the development and promotion of human health.

\section{Implementation of Health Related Issues in Bangladesh}

\section{A. A Short History of Health Administration in Bangladesh}

Bangladesh joined the WHO on May 19, 1972 when she got independence. Bangladesh agreed to observe all of these principles and to implement these at the national level. Before accepting the world standard, Bangladesh had maintained noticeable tradition on health and medical care. At the time of the Vedas (c 1500-500 BC), Ayurveda (meaning the "Science of life"), medicine was practiced. Then the Unaini Tibbi came in around $600 \mathrm{AD}$. It was followed by Homeopathy between 1810 and 1839 AD.

In 1901, Ayurvedic medicine factory Sakti Oushadhalaya was established in Dhaka and in 1912, a full-fledged Education and Health Governmental Department was

December 20, 1971; the Principles on the Effective Prevention and Investigation of Extra-legal, Arbitrary and Summary Executions, 1989, recommended by Economic and Social Council resolution 1989/65 of May 24, 1989; the Principles for the protection of persons with mental illness and the improvement of mental health care, 1991, adopted by General Assembly resolution 46/119 of December 17, 1991; the United Nations Rules for the Protection of Juveniles Deprived of their Liberty, 1990, adopted by the General Assembly resolution 45/113 of December 14, 1990; the United Nations Standard Minimum Rules for Non-custodial Measures (The Tokyo Rules), adopted by General Assembly resolution 45/110 of December 14, 1990; the Standard Minimum Rules for the Treatment of Prisoners, adopted by the First United Nations Congress on the Prevention of Crime and the Treatment of Offenders, held at Geneva in 1955, and approved by the Economic and Social Council by its resolution 663 C (XXIV) of July 31, 1957 and 2076 (LXII) of May 13, 1977.

53 The following are the health-related instruments adopted by Amnesty International: the Declaration on the Participation of Health Personnel in the Death Penalty, 1981, 1988 (This Declaration was formulated by the Medical Advisory Board of Amnesty International in 1981 and revised in 1988 in the light of developments on the issue); the London Declaration, 1995 (Amnesty International Health Professionals Network, London, May 21, 1995).

54 The ICPMS adopted the Oath of Athens in 1980.

55 The IUPsyS works to promote "the development, representation and advancement of psychology as a basic and applied science nationally, regionally, and internationally” (IUPsyS Statutes, art. 5). The IUPsyS represents psychology in its full breadth as a science and a profession. See IUPsyS, Aims of IUPsyS, available at http://www.iupsys.net/index.php/about/aims (last visited on July 31, 2010).

56 The FIGO is the only worldwide organization that groups obstetricians and gynecologists from 124 countries/territories. The FIGO's mission is to promote the wellbeing of women and to raise the standards of practice in obstetrics and gynecology. See FIGO, About the FIGO, available at http://www.figo.org/about (last visited on July 31, 2010). The FIGO passed the Resolution on Violence Against Women in 1997. 
created.57 Recently, RIHD (Pongu Hospital), Shishu Hospitals, and the Bangabandhu Sheikh Mujib Medical University were established in 1981 and 1999, respectively.58

\section{B. Health Issues in the Bangladesh Constitution of 1972}

The Constitution of the People's Republic of Bangladesh considers the health issue very seriously. Constitution extensively covers this issue. Legally speaking, all rights enshrined from the Constitution can be divided into the two broad categories: (a) Civil and Political Rights (in Part III titled, Fundamental Rights: Articles 27 - 44) and (b) Economic, Social and Cultural Rights (in Part II under the heading, Fundamental Principles of State Policy: Articles 8 - 25). The first category concerns with judicially enforceable rights subject to such restrictions as mentioned in those provisions. If any of these rights are infringed the victim or the aggrieved person can go to the High Court Division of the Supreme Court for redress. 59 The second category rights are not judicially enforceable, but kept as constitutional principles.

Article 16 of the Bangladesh Constitution [Rural Development and Agricultural Revolution] lays down that "the State shall adopt effective measures to bring about a radical transformation in the ... improvement of ... public health, 60 in those areas, so as progressively to remove the disparity in the standards of living between the urban and rural areas.” Article 18 of the Bangladesh Constitution provides the raising of the level of nutrition and the improvement of public health as the primary duties of the State.

57 The following are the 20th century's developments of health and medicine in Bangladeshi; in 1914, Sadhana Oushadhalaya in Dhaka was established; in 1919 in the Administrative Reform Act of Montage Chelmsford, the responsibility of health, sanitation and health statistics were bestowed on the provincial government; in 1930, the Simon Commission recommended the formation of a central health board for coordination and development of health services in different provinces; in the same year, the All India Institute of Hygiene and Public Health was established in Calcutta, the capital of Bengal, with the financial assistance from the Rockefeller Foundation; in 1943, in the backdrop of The Second World War and famine, the Government of India appointed a Committee under the leadership of Sir Joseph Bhore for survey and development of health services. The Bhore Committee Report used the term "comprehensive health care" for the first time in India in 1946. By comprehensive services, the Bhore Committee meant provision of integrated, preventive, curative and promotional health services to every individual residing in a defined geographic area. In 1946, the Dhaka Medical College was established; in 1950, the Pakistan Legislative Assembly passed Conscription Act thus making obligatory for doctors to serve in the government health sector; in 1953 the Shahid Suhrawardy Hospital was established; in 1967, the Institute of Post Graduate Medicine and Research ("IPGMR") was established. See National Encyclopedia of Bangladesh (Banglapedia) $42-47$ (1 st $^{\mathrm{ed}}$. 2003).

9 BANGLADESH Const. art. 44, para. 1.

60 Though the Public Health (Emergency Provisions) Ordinance, 1944 (Ordinance No. XXI of 1944), does not define the concept 'Public Health' in section 2, but section 2 (e) of the said Act says that "Public health services" and "public health establishment" include respectively sanitary, water-supply, vaccination, sewerage disposal, drainage and conservancy services and establishment maintained for the purposes of such services, and any other service or establishment of a local authority which the government may be notification in the official Gazette declare to be a public health service or public health establishment for any purpose of this Ordinance. 
This article stipulates that "the State shall adopt effective measures to prevent the consumption, except for medical purposes or for such other purposes as may be prescribed by law, of alcoholic and other intoxicating drinks and drugs which are injurious to health." Article 53 of the Bangladesh Constitution specifies the removal of the President of Bangladesh in case of physical or mental incapacity. ${ }^{61}$ The duly constituted report of the Medical Board would be a ground for the Parliament to take the decision to discharge the President from his office. 62 The intense discussion shows the importance of the health issues even though the enlighten provisions are kept with those rights not being judicially enforceable.

\section{Health Issues in National Laws in Bangladesh}

Since the independence in 1971, the Government of Bangladesh has passed many laws regarding health issues. 63 These laws were enacted to serve multiple purposes, ranging from identifying products detrimental for human health 64 to making people

61 BANGLAdesh Const. art. 53.

62 Id.

63 The list of these laws include the Vaccination Act, 1880 (Bengal Act V of 1880); the Epidemic Diseases Act (Act No. III of 1897); the Lepers Act (Act No. III of 1898); the Glanders and Farcy Act (Act No. XIII of 1899); the Mining Settlements Act (Bengal Act II of 1912); the White Phosphorus Matches Prohibition Act (Act No. V of 1913); the Medical Degrees Act (Act No. VII of 1916); the Juvenile Smoking Act, 1919 (Bengal Act II of 1919); the Public Health (Emergency Provisions) Ordinance (Ordinance No. XXI of 1944); the Embankment and Drainage Act (East Bengal Act No. 1 of 1952); the Undesirable Advertisements Control Act (East Bengal Act No. XV of 1952); the Pure Food Ordinance (East Pakistan Ordinance No. LXVIII of 1959); the Civil Aviation Ordinance, the Eye Surgery (Restriction) Ordinance,(Ordinance No. LI of 1960); the Medical Colleges (Governing Bodies) Ordinance (Ordinance No. XIII of 1961); the Allopathic System (Prevention of Misuse) Ordinance (Ordinance No. LXV of 1962); the Cantonment Pure Foods Act (Act No. XVI of 1966); the Bangladesh College of Physicians and Surgeons Order (President's Order No. 63 of 1972); the Children Act (XLII of 1974); the Bidi-Manufacturer (Prohibition) Ordinance (Ordinance No. LVII of 1975); the Pharmacy Ordinance (Ordinance No. XIII of 1976); the Prevention of Malaria (Special Provisions) Ordinance (Ordinance No. IV of 1978); the International Center for Diarrhoeal Disease Research, Bangladesh Ordinance (Ordinance No. LI of 1978); the Medical and Dental Council Act (Act No. XVI of 1980); the Medical Practice and Private Clinics and Laboratories (Regulation) Ordinance (Ordinance No. IV of 1982); the Drugs (Control) Ordinance (Ordinance No. VIII of 1982); the Bangladesh Unani And Ayurvedic Practitioners Ordinance (Ordinance No. XXXII of 1983); the Fish and Fish Products (Inspection and Quality Control) Ordinance (Ordinance No. XX of 1983); the Bangladesh Homeopathic Practitioners Ordinance (Ordinance No. XLI of 1983); the Bangladesh Nursing Council Ordinance (Ordinance No. LXI of 1983); the Breast-Milk Substitute (Regulation of Marketing) Ordinance (Ordinance No. XXXIII of 1984); the Livestock Research Institute Ordinance (Ordinance No. 143 of 1984), the Drugs (Supplementary Provisions) Ordinance (Ordinance No. XIII of 1986); the Iodine Obhab Jonit Rog Protirod Ain (Act No. X of 1989); the Madok Drobbo Niontron Ain (Act No. 20 of 1990); the Paromanobik Nirapotta $O$ Bikiron Niontron Ain (Act No. 21 of 1993); the Bangabandhu Shiekh Mujibur Rahman Medical Bishwabidhalaya Ain (Act No. 1 of 1998); the Transplantation of Organ in Human Body Act (Act No. V of 1999); the Bangladesh Protibondhi Kollan Ain, the Safe Blood Transfusion Act (Act No. XII of 2002); and the Dhumpan o Tamakjat Drobbo Babohar (Niontron) Ain (Act No. 11 of 2005).

64 E.g., the White Phosphorus Matches Prohibition Act (Act No. V of 1913); the Pure Food Ordinance (East Pakistan Ordinance No. LXVIII of 1959); the Breast-Milk Substitute (Regulation of Marketing) Ordinance (Ordinance No. 
aware of different diseases, 65 from setting up medical institutions 66 to managing human resources involved in health sector. 67 There are other laws concerned with health. For example, the Penal Code of 1860; 68 the Local Government (City Corporation) Ordinance (Ordinance No. XVI of 2008); 69 and the Local Government (Paurashava) Ordinance (Ordinance No. XVII of 2008) contain elaborate provisions relating to health. Under section 15 (a) of the Bangladesh Hotels and Restaurants Ordinance of 1982 (Ordinance No. LII of 1982), the Controller of Hotels may prohibit, by order in writing, prohibit, within one hundred yards of a three star or above hotel, the carrying out of any trade, profession, occupation or industry which in his opinion is likely to be injurious to the health and well being of guests or customers or a hazard to their safety. The Irrigation Act (Act No. II of 1876) empowers the government to prohibit any canal the formation of which may injure the public health (section 40) and to do necessary drainage work for public health (section 43). Under section 42 of the Court of Wards Act (Act No. IX of 1879), a guardian appointed to the care of a ward shall be charged with the custody of the ward, and must look into his maintenance, health, and, if he be a minor, to his education.

Most of health related laws in Bangladesh are so outdated that they may not meet the demand of present time. New laws are often enacted or at least amended

XXXIII of 1984), etc.

65 E.g., the Epidemic Diseases Act (Act No. III of 1897); the Lepers Act (Act No. III of 1898), etc.

66 E.g., the Bangabandhu Shiekh Mujibur Rahman Medical Bishwabidhalaya Ain (Act No. 1 of 1998); the Bangladesh Nursing Council Ordinance (Ordinance No. LXI of 1983), etc.

67 E.g., the Bangladesh Nursing Council Ordinance (Ordinance No. LXI of 1983), etc.

68 Chapter XIV of the Penal Code (XLV of 1860) deals with Offences Affecting the Public Health, Safety, Convenience, Decency and Morals ( $\$ 264-294 \mathrm{~B})$ and incorporate elaborate provisions relating to different issues affecting health. The issues which are covered within this Chapter are: Public nuisance (\$268), Negligent act likely to spread infection of disease dangerous to life ( $\$ 269)$, Malignant act likely to spread infection of disease dangerous to life $(\$ 270)$, Disobedience to quarantine rule (\$271), Adulteration of food or drink intended for sale (\$272), Sale of noxious food or drink (\$273), Adulteration of drugs ( 274 ) Sale of adulterated drugs ( 275$)$, Sale of drug as a different drug or preparation (\$276), Fouling water or public spring or reservoir (§277), Making atmosphere noxious to health (\$278) Rash driving or riding on a public way (\$279), Rash navigation of vessel ( $\$ 280)$, Exhibition of false light, mark or buoy (\$281), Conveying person by water for hire in unsafe or over-loaded vessel (\$282), Danger or obstruction in public way or line of navigation (\$283) Negligent conduct with respect to poisonous substance $(\S 284)$, Negligent conduct with respect to fire or combustible matter (\$285), Negligent conduct with respect to explosive substance (§286), Negligent conduct with respect to machinery (\$287), Negligent conduct with respect to pulling down or repairing buildings ( $\$ 288$ ), Negligent conduct with respect to animal ( $\$ 289)$ Punishment for public nuisance in cases not otherwise provided for ( $\$ 290)$, Continuance of nuisance after injunction to discontinue ( $\$ 291)$, Sale of obscene books, etc. ( $\$ 292)$, Sale of obscene objects to young person ( $\$ 293)$, Obscene acts and songs ( 294 ), Keeping lotteryoffice ( $\$ 294 \mathrm{~A})$, Offering of prize in connection with trade $(\$ 294 \mathrm{~A})$.

69 The Ordinance repealed the previous the City Corporations laws i.e. the Chittagong City Corporation Ordinance (Ordinance No. XXXV of 1982), the Dhaka City Corporation Ordinance (Ordinance No. XL of 1983), the Khulna City Corporation Ordinance (Ordinance No. LXXII of 1984), the Rajshahi City Corporation Act (At No. XXXVIII of 1987), the Sylhet City Corporation Act (Act No. X of 2001) and the Barishal City Corporation Act (Act No. XI of 2001) under $\S 125$ of the Ordinance. 
frequently to meet the changing needs of the society. In Bangladesh, however, many laws relating to the health issues have not been amended for the last fifteen to twenty years, despite of the major scientific developments in this period. For example, many laws 70 were last amended in 1973 by the Revision and Declaration Act (Act No. VIII of 1973) 71 which did not introduce any significant changes. This Act simply adopted the laws that had been enacted before the independence of Bangladesh. 72 In most cases the Act substituted words like 'Bangladesh' for 'Pakistan' or 'East Pakistan,' 'Government' for 'Central Government' or 'Provincial Government' or 'Appropriate Government,' 'taka' for 'rupee' or 'rupees' or 'Rs.,' 'High Court Division' for 'High Court,' etc. only and after that these laws are not reviewed to fit these with the need of the present time. The Table VI-1 shows the amended years of laws.

Table VI-1: Amendments of the Health Related Laws in Bangladesh

\begin{tabular}{|l|c|}
\hline \multicolumn{1}{|c|}{ The Name of Law } & Amended Year \\
\hline $\begin{array}{l}\text { The Bangladesh College of Physicians and Surgeons Order, 1972 } \\
\text { (President's Order No. 63 of } 1972\end{array}$ & 1976 \\
\hline The Pharmacy Ordinance, 1976 (Ordinance No. XIII of 1976) & 1984 \\
\hline $\begin{array}{l}\text { The Medical Practice and Private Clinics and Laboratories (Regulation) } \\
\text { Ordinance, 1982 (Ordinance No. IV of 1982) }\end{array}$ & 1998 \\
\hline $\begin{array}{l}\text { The International Center for Diarrhoeal Disease Research, } \\
\text { Bangladesh Ordinance, 1978 (Ordinance No. LI of 1978) }\end{array}$ & 1995 \\
\hline $\begin{array}{l}\text { The Breast-Milk Substitute (Regulation of Marketing) Ordinance, 1984 } \\
\text { (Ordinance No. XXXIII of 1984) }\end{array}$ & \\
\hline
\end{tabular}

Source: Compiled by the author

70 The Vaccination Act (Bengal Act V of 1880); the Epidemic Diseases Act (Act No. III of 1897); the Lepers Act, 1898 (Act No. III of 1898); the Glanders and Farcy Act, 1899 (Act No. XIII of 1899); the Mining Settlements Act, 1912 (Bengal Act II of 1912); the White Phosphorus Matches Prohibition Act, 1913 (Act No. V of 1913); the Medical Degrees Act, 1916 (Act No. VII of 1916); the Juvenile Smoking Act, 1919 (Bengal Act II of 1919); the Public Health (Emergency Provisions) Ordinance, 1944 (Ordinance No. XXI of 1944); the Undesirable Advertisements Control Act, 1952 (East Bengal Act No. XV of 1952); the Eye Surgery (Restriction) Ordinance, 1960 (Ordinance No. LI of 1960); the Medical Colleges (Governing Bodies) Ordinance, 1961 (Ordinance No. XIII of 1961); the Allopathic System (Prevention of Misuse) Ordinance, 1962 (Ordinance No. LXV of 1962); and the Cantonment Pure Foods Act, 1966 (Act No. XVI of 1966).

71 As amended by the Bangladesh Laws (Revision and Declaration) (Amendment) Act, 1974 (Act No. LIII of 1974) as amended by the Bangladesh Laws (Revision and Declaration) (Second Amendment) Act, 2000 (Act No. XL of 2000) as amended by the Bangladesh Laws (Revision and Declaration) (Third Amendment) Act, 2001 (Act No. XLVIII of 2001). Pertinent to mention here that the Bangladesh Laws (Revision and Declaration) Act, 1973 (Act No. VIII of 1973).

72 The oldest law as applicable in Bangladesh is of 1836. In between 1836-1971, Bangladesh was part of India (till 1947) and subsequently Pakistan (1947-1971). The laws which were prevailed and necessary before 1971 were duly recognized by this Act with necessary modifications in those laws. 
Some laws were enacted after the creation of Bangladesh like the BidiManufacturer (Prohibition) Ordinance (Ordinance No. LVII of 1975); the Prevention of Malaria (Special Provisions) Ordinance (Ordinance No. IV of 1978); the Medical and Dental Council Act (Act No. XVI of 1980); the Fish and Fish Products (Inspection and Quality Control) Ordinance (Ordinance No. XX of 1983); the Bangladesh Unani And Ayurvedic Practitioners Ordinance (Ordinance No. XXXII of 1983); the Bangladesh Homeopathic Practitioners Ordinance (Ordinance No. XLI of 1983); the Bangladesh Nursing Council Ordinance (Ordinance No. LXI of 1983). These laws are not considered for amendment in last 25-35 years by the lawmakers, which clearly shows their reluctance to address the necessity of making these laws updated in line with the innovation and improvement in developing countries.

\section{Health Care System}

\section{Regulatory Framework}

The Ministry of Health and Family Welfare is primarily responsible to look after and administer health related issues in Bangladesh. At national level, it has four main divisions called Directorates (Director General of Health Services, "DGHS”), Director General of Family Planning ("DGFP"), Directorate of Nursing Services ("DNS") and Directorate of Drug Administration ("DDA"). Director-General of each directorate is the executive head performing all health service related administrative tasks and health program implementation. The DGFP is represented by a Deputy Director, while DGHS is represented by a Civil Surgeon. DGHS offers school heath services at the district level. In the certain districts under the management of the deputy director of DGFP, there is a facility called Maternal and Child Health Welfare Centre ("MCWC") for both indoor and outdoor patients. The MCWC is headed by a medical officer.

At Thana level,73 Thana Health Complex ("THC") provides first-level referral services to the population. The THC is the health service and administrative centre of a Thana. It is headed by a Thana Health and Family Planning Officer. There are a total of 397 THCs in the country. Usually 9 doctors are posted in a THC. Among them, three are specialists-medical officers (one each in medicine, surgery and gynecology), one medical officer for maternal and child health, and the other dental surgeon. A Union sub-centre ("USC") or Health and Family Welfare Centre ("HFWC") located in each union to provide static health and family planning services to the population in the union, are under the management of DGHS, while HFWCs are run by DGFP. These

73 Thana is the third layer of four-tire administrative setup in Bangladesh. The layers are divisions, district/zilla, thana/ upazilla and union. 
facilities are also called Union Health and Family Welfare Centers ("UHFWC"). One graduate doctor usually manages a USC with other heath colleagues and support staff. In addition, the supervisory staffs of field level health workers, namely, Assistant Health Inspector ("AHI") and Family Planning Inspector ("FPI") have their offices in the UHFWCs. 74 In autonomous and semi-autonomous level, each local government has responsibilities under the law.

\section{Health and Local Government}

In Bangladesh, the local government such as city corporations, zilla parishads, upazilla parishads and union parishad play a leading role in administration. All of these local governments shall constitute the Standing Committees for dealing with various social and health issues. The relevant laws empower the local governments to perform some mandatory and optional duties.

\section{Health Related Issues in Universities}

There are thirty public universities in Bangladesh. All of them were established by special laws which empower the universities to supervise the residence and discipline of the students, and to promote their health. 75 Unfortunately, however, all the universities are still far behind the standard to ensure health of students, faculties, officials and staffs. The residential hostels are over-crowded; foods are sub-standard; the adjacent areas to these residential hostels are neither clean nor hygienic.

\section{Health Issues within the Cantonment Areas}

In Bangladesh, all the cantonments are established in accordance with the provisions of the Cantonment Act (Act No. II of 1924). This Act contains the following provisions as to health: Public Safety and Suppression of Nuisances (Chapter IX, §§ 118-127); Sanitation and the Prevention and Treatment of Disease (Chapter X, §§ 128-178); Control Over Buildings, Streets, Boundaries, Trees, etc. (Chapter XI, §§ 178A-197). Chapter XIII of the Cantonment Act contain provisions relating to Water-Supply, Drainage and Lighting. In addition, Chapter XIV of the Cantonment Act ( $\S 235-240$ )

74 For details, see the official website of Ministry of Health and Family Welfare, available at http://www.mohfw.gov.bd/ facility.htm (last visited on Nov. 20, 2008).

75 See e.g., the Agricultural University Ordinance, §5(k), 1961 (East Pakistan Ordinance No. XXVIII of 1961), the Engineering and Technological University Ordinance, §5(k), 1961 (East Pakistan Ordinance No. XXXVI of 1961), the Rajshahi University Act, §4(n), 1973 (Act No. XXVI of 1973), the Jahangirnagar University Act, §5(m), 1973 (Act No. XXXIV of 1973), and the Dhaka University Order, art. 4, para. m (President's Order No. 11 of 1973). 
provides the power to remove brothels and prostitutes, removal of lewd and disorderly persons from cantonment and penalty for offences. The Cantonment authorities should still be more responsible, active and vigilant to perform their duties because the heath conditions of the cantonments remains to be improved.

\section{Health Related Cases before the Bangladesh Courts}

The judiciary of Bangladesh positively ruled issues relating to health. In a number of cases the Courts of Bangladesh played an influential role in implementing the right to health. The courts even held that law permits granting of bail on the ground of illhealth to sick and infirm persons even in a case where there are reasonable grounds for refusing bail.76 In the case of Hussain Mohammad Ershad v. Bangladesh, the Court held that "...though the Universal Declaration of Human Rights or the Covenants unless incorporated in the domestic law are not enforceable in national courts, the national courts may draw upon those principles if domestic laws are inconsistent with those." 77

In the case of Dr. Mohiuddin Farooque v. Bangladesh, the Court held that "right to life under Articles 31 and 32 of the Constitution not only means protection of life and limbs necessary for full enjoyment of life, but also includes, among others, protection of health and normal longevity of an ordinary human being from man made hazards unless that threat is justified by law." 78 Thus, the Collector of Customs was directed to take effective measures to prevent importation of contaminated food items till foolproof effective methods are evolved by the authorities.

While ruling on an issue of ill effects of use of tobacco and related products, in the case of Professor Nurul Islam v. Bangladesh, the Court held that "right to life means right to sound mind and health and state has a duty to protect the ordinary human beings from the ill effects of use of tobacco related products. Advertisement of cigarette and cigarette related products are detrimental to life and body of the people and violation of the fundamental right to life and as such advertisement of tobaccorelated products are to be stopped." 79

The Appellate Division of the Supreme Court of Bangladesh, in the case of Department of Narcotics Control v. Crown Beverage Ltd. Senakalyan Bhaban (12th Floor) 195, Motijheel Commercial Area, Dhaka and another 2006, refused to grant licences in favour of respondent who manufactured two beverage called 'hunter' and 'crown' on ground of public health after taking licences from the Department of

\footnotetext{
State v. Jobaida Rashid, 49 DHAKA L. ReP. (APp. Div.) 119 (Sup. Ct. 1997) (Bangladesh).

2001 Bangladesh L. Decs. (App. D) 69.

Dr. M. Farooque v. Bangladesh, 48 DHAKA L. REP. 438 (High Ct. 1996) (Bangladesh).

52 DHAKA L. REP., 413.
} 


\section{Narcotics. 80}

In the case of Dr. Mohiuddin Farooque v. Bangladesh and Others, 81 Dr. Mohiuddin Farooque filed a writ petition on October 3, 1994 requesting the intervention of the High Court Division of the Supreme Court in restoring the public medical services and care all over the country, which had been disrupted by the continuous strike of the BCS (Health) Cadre doctors. In that Writ Petition the petitioner challenged the continuance of strike by the doctors of all the government medical hospitals, health complexes and centers. It was submitted that due to a long strike by the government medical hospitals, health complexes and centers, the whole system for providing treatment for the people become paralysed, and the sufferings of the people knew no bounds. The High Court Division of the Supreme Court issued a Rule granting a mandatory injunction to call off the strike of the BCS (Health) Cadre doctors of all the government medical hospitals, health complexes and centers immediately within 24 hours from the date of service of notice and to join their respective offices. Thus, it is evident that though the medical professionals have the right to assembly, association, opinion, thought and conscience, they used to be directed to call off the strike on the ground of public health.

\section{E. National Health Policy}

The Government of Bangladesh follows the Russian system of five-year plans. Every plan contains a chapter on health issue. The health chapter of the Fourth Five-Year Plan (1990-95) began with the premise that access to health is a fundamental right of a person. The Fifth Five-Year Plan (1997-2002) states that: "[P]roviding medical care is the constitutional obligation of the government." In response to the changing health situation of the country, it is urgently required to introduce reforms in the health sector, particularly in the areas of management structure, service delivery mechanisms and utilization of both public and private sector resources. 82

The National Health Policy of Bangladesh has a long history. As of 2008, however, no formal policy has been initiated by the government though the final draft is ready. After the independence of Bangladesh in 1971, nearly a decade elapsed during which the government had strived for providing health services under the existing administrative structures that were inherited from Pakistan. During the early 1980s, however, a drug policy was adopted by the government. It attempted to rationalize drug use, manufacture, and import. The drug policy was followed by the preparation

\footnotetext{
30 Appellate Decision Cases VII (2010) 132.

81 Writ Petition No. 1783/1994 (Doctor's strike case).

82 The Fifth Five-Year Plan (1997-2002), The Health Population and Family Welfare, Ch. XXI, para. 21.1.2.
} 
of a national health policy document in the late 1980s, which was readopted and partially implemented by the government. 83

During the later part of the 1990s, the National Health Policy was in progress in line with the changes of national and global circumstances. The cabinet has approved the draft policy, but the Parliament has not yet considered adopting it. 84 In the final draft of the National Health Policy of 2008, the Government of Bangladesh claims that Bangladesh's public health system is well organized.85 It states that: " $[\mathrm{H}]$ ealth is a state of complete physical, mental and social well being and merely not an absence of disease or infirmity. Health is universally regarded as an important index of human development. Health is also a fundamental right of the population." 86

The government gives priority to the health sector development as an integral part of overall socioeconomic development. It is committed to the "Health of All" ("HFA") and the "Primary Health Care" ("PHC") approach. To obtain these goals, the government follows the principle of universal health coverage and accessibility, priority to the poor and the most vulnerable groups, improvement in the quality of life, and promotion of health. The Health and Population Sector Strategy ("HPSS") of 1998 forms the basis for the national health policy in Bangladesh. It incorporates the following key principles: greater orientation to client needs, especially those of women; improved quality, efficiency and equity of government health services; provision of a package of essential health services; expanded private sector role in providing health and population services; one-stop shopping via co-location of services; and expanded cost recovery and improved efficiency of resources by the public sector. In the context of changing health situation in Bangladesh, reforms in the health sector will be essential. It should include decentralized health management systems. 87

\section{Conclusion}

Sound health is the most vital condition to enjoy human rights. Therefore, Health as human rights should be considered more seriously in national as well as international

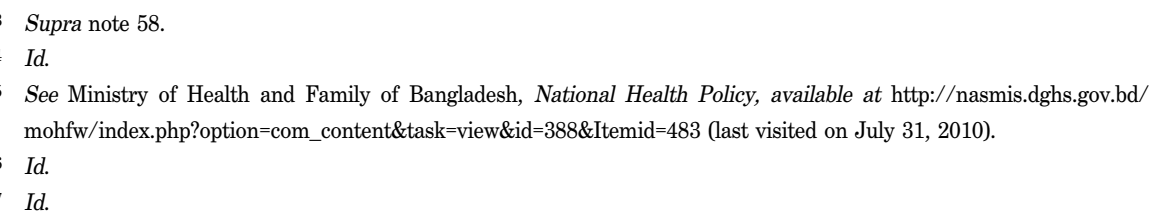


legal context. The right to health is not explicitly laid down at international human rights legal instruments. Elements and sprites of health, however, are already embodied there. International legal instruments consider health as fundamental human right to the highest attainable standard of living. These include the following right: to reproductive and sexual health; right to equal access to adequate health care and health-related services; regardless of sex, race, or other status; to equitable distribution of food, right to access to safe drinking water and sanitation; to an adequate standard of living and adequate housing, right to a safe and healthy environment; to a safe and healthy workplace; to adequate protection for pregnant women in work proven to be harmful to them; to freedom from discrimination and discriminatory social practices, like female genital mutilation, prenatal gender selection, and female infanticide; to education and access to information relating to health, including reproductive health and family planning to enable couples and individuals to decide freely and responsibly all matters of reproduction and sexuality; and to appropriate environment for physical and mental development of child.

Bangladesh has been enjoying economic prosperity. However, the government of Bangladesh did not pay much attention to the civil right in the past. Recently, the situation has improved and the government has taken some meaningful initiatives. It is urgent for the government to put more efforts to meet the global standards. In addition, the government should encourage the civic society to assist and co-operate with all initiatives relating to health issue.

\section{Annex \\ Draft Patient's Charter of Bangladesh}

The Government of Bangladesh declares in the Fourth Five-Year Plan (1990-95) that access to health is a fundamental right of person. The government may think for the publication of a Patient's Charter in Bangladesh. The Charter may contain the following provisions:

\section{A. Role of Government}

(a) In Government health centers, no patients can be discriminated due to, inter alia, status, age, sex, class, color, religion, and race. The government shall ensure the patient to receive the health care service on the basis of his or her clinical need, not 
on his or her ability to pay, lifestyle, or any other factors.

(b) The Government can appoint an ombudsman. The ombudsman shall receive grievances and take swift action related to misadministration in the health sector, expired medicines, and other issues of concern.

(c) The Government may consider introducing compulsory health insurance system in Bangladesh so that the patients who are victims of negligent or wrong treatment by health professionals can be compensated.

(d) The Government shall operate a regular and continuous awareness program on various print and electronic media regarding any new and unknown diseases which may turn into endemic.

\section{B. Role of Health Professionals including Physicians, Nurses, and Health Centers' Officials}

(a) Doctors shall give a hearing to the patient and write down appropriate medical history of the patient systematically.

(b) The health professionals must obtain a written informed consent from a patient or from his or her legal guardian in terms of the consequences of the treatments. This provision can be alleviated in case of a serious patient whose life is in danger.

(c) In case of emergency, the fastest treatment shall be provided. If a doctor fails to give initial treatment in emergent situation effectively to a patient, the doctor should not offer any further treatment. In that case, the doctor shall refer the patient to other specialists.

(d) When the doctor may prescribe a drug that is not available in the pharmacy, the pharmacist used to advise the patient to take similar type of drug of other company. Even in this case, however, the pharmacists must not force the patient to take this different medicine from the doctor's original prescription. In addition, the doctors should not prescribe a drug out of personal benefits and interest rather than the need of the patient.

(e) Hospitals should maintain the highest level of cleanliness, balanced nutrient level of patients' diet, and proper health policies, catering services, and standards.

(f) The health centers or health professionals can be awarded for their good performances and can give a mark in recognition for the contribution.

\section{Rights of Patient}

(a) The patients shall have the right to choose of diagnosis centers, blood banks, and pharmacies among the Government-approved diagnosis centers with their preference. For the easier recognition, the "Government approved certificate" must 
be placed in front of each diagnosis center, blood bank, and pharmacy.

(b) A pregnant woman shall have the right to choose a midwife, a General Practitioners ("GP"), or consultant obstetrician who will be responsible for looking her after. She will also have the option for the type of care.

(c) The patients, when taking treatment from their physicians, shall be entitled to have the full addresses with their contact numbers.

(d) The patients shall have the right to complain against health professional or medical center. The visitors can any opinions to the hospitals. When the hospital takes any suggestion, it should respond to it in due course.

(e) The hospital should keep the privacy or any other information of the patients which it obtained in the course of treatment. Under the extremely necessary situation to the interests of the society including infectious and vulnerable diseases, however, the doctor shall not be bound by this practice. 
